\title{
Retention and Viability Characteristics of Mammalian Cells in an Acoustically Driven Polymer Mesh
}

Zhaowei Wang

Cleveland State University

Paul Grabenstetter

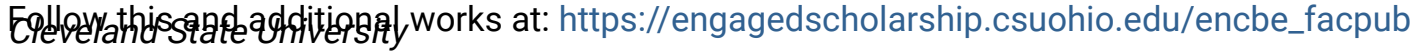
Donart of the Reke Biochemical and Biomolecular Engineering Commons, and the Membrane Science

Ease Pestern Reserve University

How does access to this work benefit you? Let us know!

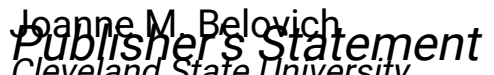

Cleveland'State University

This is the accepted version of the following article: Wang, Z., Grabenstetter, P., Feke, D. L., , \&

Belovich, J. M. (2004). Retention and Viability Characteristics of Mammalian Cells in an

Acoustically Driven Polymer Mesh. Biotechnology Progress, 20(1), 384 - 387. doi:10.1021/

bp034105s, which has been published in final form at http://onlinelibrary.wiley.com/doi/

10.1021/bp034105s/abstract

\section{Original Citation}

Wang, Z., Grabenstetter, P., Feke, D. L., , \& Belovich, J. M. (2004). Retention and Viability Characteristics of Mammalian Cells in an Acoustically Driven Polymer Mesh. Biotechnology Progress, 20(1), 384 - 387.

doi:10.1021/bp034105s

\section{Repository Citation}

Wang, Zhaowei; Grabenstetter, Paul; Feke, Donald L.; and Belovich, Joanne M., "Retention and Viability Characteristics of Mammalian Cells in an Acoustically Driven Polymer Mesh" (2004). Chemical \& Biomedical Engineering Faculty Publications. 42.

https://engagedscholarship.csuohio.edu/encbe_facpub/42

This Article is brought to you for free and open access by the Chemical \& Biomedical Engineering Department at EngagedScholarship@CSU. It has been accepted for inclusion in Chemical \& Biomedical Engineering Faculty Publications by an authorized administrator of EngagedScholarship@CSU. For more information, please contact library.es@csuohio.edu. 


\title{
Retention and Viability Characteristics of Mammalian Cells in an Acoustically Driven Polymer Mesh
}

\author{
Zhaowei Wang, † Paul Grabenstetter, ${ }^{\dagger, \S}$ Donald L. Feke, ${ }^{\ddagger}$ and J oanne M. Belovich*,† \\ Department of Chemical and Biomedical Engineering, Cleveland State University, Cleveland, Ohio 44115-2425, \\ and Department of Chemical Engineering, Case Western Reserve University, Cleveland, Ohio 44106-7217
}

\begin{abstract}
A processing approach for the collection and retention of mammalian cells within a high porosity polyester mesh having millimeter-sized pores has been studied. Cell retention occurs via energizing the mesh with a low intensity, resonant acoustic field. The resulting acoustic field induces the interaction of cells with elements of the mesh or with each other and effectively prevents the entrainment of cells in the effluent stream. Experiments invol ving aqueous suspensions of polystyrene partides were used to provide benchmark data on the performance of the acoustic retention cell. Experiments using mouse hybridoma cells showed that retention densities of over 1.5 $\times 10^{8} \mathrm{cell} / \mathrm{mL}$ could be obtained. In addition, the acoustic field was shown to produce a negligible effect on cell viability for short-term exposure.
\end{abstract}

\section{Introduction}

Efficient production of secreted products from anchorage-independent mammalian cells requires use of a method to recycle cells to the reactor with continuous removal of the cell-free product stream. In general, mechanically based filtration units have been used for this purpose. More recently, acoustic fields have been used for the recovery or collection of cells from flowing liquids. Acoustically based devices have been used to aggregate mammalian cells and recycle the concentrated cell stream to the bioreactor (Kilburn et al., 1989; Ryll et al., 2000; Trampler et al., 1994; Pui et al., 1995; Doblhoff-Dier et al., 1994; Gaida et al., 1996). In all these methods, an acoustic field is established within a chamber filled with processing fluid but with no other solid material present. Acoustic resonance is generated within the chamber from the interference of waves launched from the emitter and those reflected from an opposite wall of the chamber. In devices using one-dimensional acoustic fields, cells can be readily entrained in flows that are not oriented parallel to the principal direction of propagation of the acoustic field.

We have developed an alternative acoustic processing approach for cell collection that is different in several aspects compared to the methods described above. In our method the acoustic chamber is filled throughout with a highly porous polymer mesh having pores up to 100 times larger than the size of the cells to be collected. The acoustic field interacts strongly with the polymer mesh (and not just the walls of the chamber). This results in a complex, three-dimensional acoustic field, with spacing between nodes determined by the morphology of the porous mesh as well as the frequency of the applied acoustic field. Cells suspended in fluid within the chamber can be driven to aggregate with each other or driven to interact with the elements comprising the porous mesh. Also, the tortuosity in flow path induced by the porous mesh prevents the entrainment of cells in flows perpendicular to the principal direction of propagation of the acoustic field. Previously we have shown that this device can be used to collect and retain micron-sized solid particles efficiently from flowing suspensions with virtually no pressure drop losses (Gupta and Feke, 1997, 1998) at linear flow rates up to $0.5 \mathrm{~cm} / \mathrm{s}$. The retained particles were suspended individually or in small flocs that dispersed upon termination of the acoustic field.

In this paper, we report on the effectiveness of this particle collection approach for the retention of mammalian cells from flowing suspension. The acoustic contrast factor, which is a measure of the susceptibility of the particles to the acoustic field, is 30\% smaller for mammalian cells than for the polystyrene particles used in the previous work, indicating that the efficiency of hybridoma retention is expected to be lower than that of similarly sized polystyrene particles. The effect of both short- and long-term exposure to the acoustic field on cell viability was studied. The power requirement for this device is expected to be significantly lower than that of the other acoustic filtration devices reported earlier.

\section{Materials and Methods}

The acoustic chambers used in the retention experiments consisted of a piezoel ectric lead zirconate titanate transducer (PZT, Navy Type I, EDO Electro Ceramics Corporation, model EC-64), $25.5 \times 42.2 \times 10 \mathrm{~mm}$, with fundamental frequency of $202.6 \mathrm{kHz}$, and a reflector of borosilicate glass, $25.5 \times 42.2 \times 1 \mathrm{~mm}$. The frame of the 


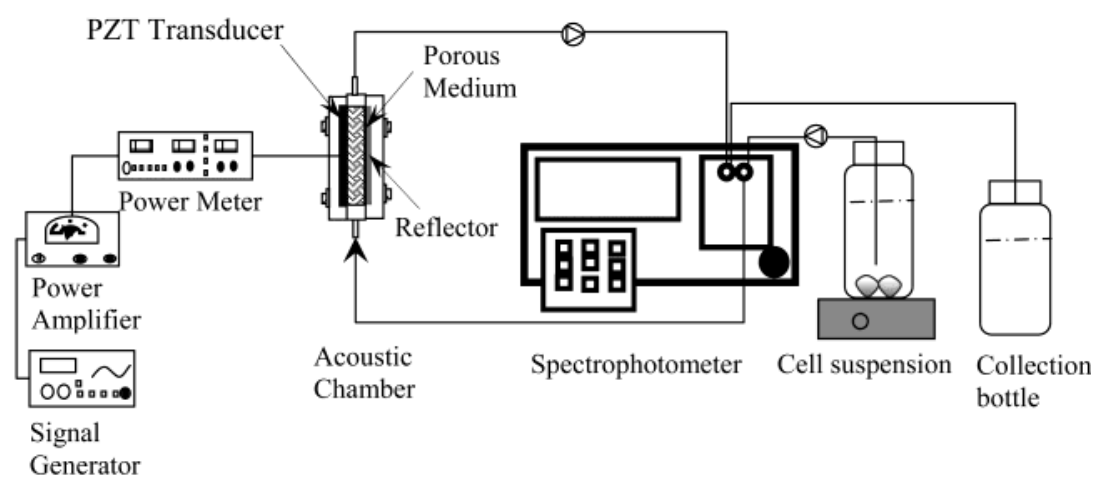

Figure 1. Schematic of the experimental setup.

chamber was constructed from acrylic. The transducer and reflector were held in place within the acrylic frame by a $0.36-\mathrm{mm}$ thick latex membrane. The internal volume of the chamber is $13 \mathrm{~mL}$. Details of the chamber design have been published previously (Rusinko, 2000). The mesh was reticulated polyester (Specialty Industrial Foam, NY) with 8 pores $/ \mathrm{cm}$, with approximate pore size of $1250 \mu \mathrm{m}$. The transducer was energized using a HP 33120A signal generator (HP, Loveland, CO), whose signal was amplified by an ENI Power Amplifier (ENI Co., Rochester, NY). Experiments were conducted at resonant frequencies near $1125 \mathrm{kHz}$, and the frequency was manually adjusted up to $\pm 5 \mathrm{kHz}$ to maintain a resonant state. Signal generator voltages were varied from 40 to $200 \mathrm{mVrms}$ in various experiments, which then affects the acoustic energy density within the chamber. Although the acoustic energy density is difficult to measure directly, it is directly related to the electrical power applied to the driving transducer, which in turn is proportional to the square of the voltage output of the signal generator. The acoustic energy density was estimated at each experimental condition by measuring the actual voltage across the transducer (attached to the cell chamber) at each signal generator voltage and using these data, as well as the chamber dimensions, in a computer model (Rusinko, 2000) of the multilayer resonating chamber.

The cell suspension was prepared using mouse hybridoma cells (SF 1-1.1.1, Anti H-2K d, ATTC HB-159, Rockville, MD) cultured in a $5 \% \mathrm{CO}_{2}$ atmosphere at $37^{\circ} \mathrm{C}$ in RPMI media (Sigma, St. Louis, MO) with $10 \%$ fetal bovine serum (Sigma). Cell counts were done in triplicate using hemacytometer and trypan blue staining. Experiments were conducted with feed suspensions of approximately $1.2 \times 10^{6} \mathrm{cell} / \mathrm{mL}$ with viabilities of $96-99 \%$.

The feed suspension was delivered to the chamber at 30-35 mL/min using a peristaltic pump (Cole-Parmer, Vernon Hills, IL). The chamber effluent was fed to a spectrophotometer (Spectronic Instruments, Rochester, NY) fitted with a Hellma flow-through cell. The absorbance was measured at $300 \mathrm{~nm}$. The spectrophotometer readings were zeroed with a sample of spent media. Calibration experiments showed a linear relationship between the absorbance and cell concentration as measured with the hemacytometer. A schematic of the experimental setup is shown in Figure 1 . In the flowthrough experiments, the effluent from the flow-through cell in the spectrophotometer was collected into a flask, and at the completion of the experiment the collection flask was analyzed for cell concentration and viability. In recycle experiments the feed stream was passed through the spectrophotometer. The chamber effluent stream was also passed through a second flow-through cell in the spectrophotometer and then returned to the

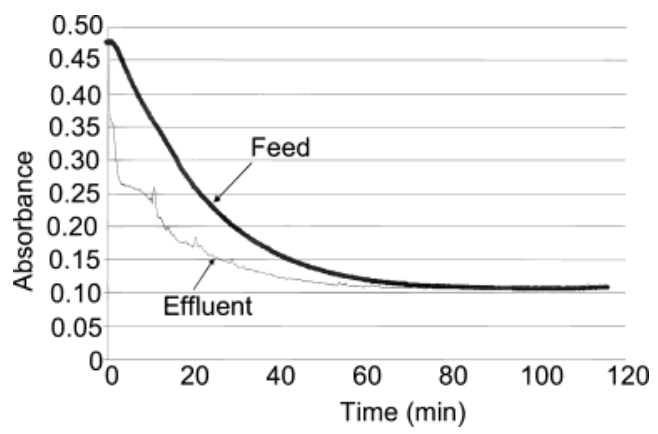

Figure 2. Relative hybridoma concentrations using the acoustic retention device operated in recycle mode (150 mV rms, 1130 $\mathrm{kHz}, 30 \mathrm{~mL} / \mathrm{min}$ ).

Table 1. Maximum Cell Concentration and Change in Cell Viability Achieved in the Acoustic Retention Device $^{a}$

\begin{tabular}{cccc}
\hline $\begin{array}{c}\text { signal } \\
\text { generator } \\
\text { voltage } \\
\text { (mV rms) }\end{array}$ & $\begin{array}{c}\text { acoustic } \\
\text { energy } \\
\text { density } \\
\left(\mathrm{J} / \mathrm{m}^{3}\right)\end{array}$ & $\begin{array}{c}\text { maximum } \\
\text { viable cell } \\
\text { concentration } \\
\text { (cells } / \mathrm{mL})\end{array}$ & $\begin{array}{c}\text { relative change } \\
\text { in viable cell } \\
\text { numberc } \\
\text { (\%) }\end{array}$ \\
\hline 100 & 0.06 & $9.4 \pm 10^{7}$ & $-3.0 \%$ \\
125 & 0.10 & $1.3 \pm 10^{8}$ & $-7.2 \%$ \\
150 & 0.14 & $1.5 \pm 10^{8}$ & $-29 \pm 8.5 \%$
\end{tabular}

a Maximum cell concentrations were obtained using $2 \mathrm{~L}$ of feed cell suspension, recycled through the chamber at flow rate of 30 $\mathrm{mL} / \mathrm{min}$; frequency $1127-1137 \mathrm{kHz}$; length of experiment $5.25 \mathrm{~h}$. Percentage change in viable cell number data was obtained from experiments using $178 \mathrm{~mL}$ of cell suspension recycled through chamber at flow rate of $30 \mathrm{~mL} / \mathrm{min}$, frequency $1125-1132 \mathrm{kHz}$; length of experiment $5 \mathrm{~h}$; average residence time in chamber 4.75 h. $\mathrm{n}=2$ for $150 \mathrm{mVrms} ; \mathrm{n}=1$ for other experiments. ${ }^{\mathrm{b}} \mathrm{U}$ sing $2 \mathrm{~L}$ of cell suspension. ${ }^{\mathrm{C}} \mathrm{U}$ sing $178 \mathrm{~mL}$ of cell suspension.

same stirred reservoir containing the feed cell suspension. Between experiments the power amplifier and signal generator were turned off, and DI water was flushed through the chamber.

\section{Results and Discussion}

Figure 2 shows the absorbance of both the chamber influent and the effluent in a sample recycle experiment. The feed concentration decreases continuously as cells are retained within the chamber until the maximum chamber capacity is reached, at about 70 min from a 420$\mathrm{mL}$ cell suspension. From measurements of the cell concentration in the collection and feed vessels, one can calculate the maximum cell concentration achieved within the chamber. As shown in Table 1, a cell concentration greater than $1.5 \times 10^{8} \mathrm{cell} \mathrm{s} / \mathrm{mL}$ was achieved within the chamber from $2 \mathrm{~L}$ of cell suspension, and the maximum cell concentration increased with the intensity of the applied acoustic field. 
Table 2. Effect of Applied Voltage and Acoustic Energy Density on Change in Cell Viability between Beginning and End of Experimentsa

\begin{tabular}{cclc}
\hline $\begin{array}{c}\text { signal } \\
\text { generator } \\
\text { voltage }(\mathrm{mVrms})\end{array}$ & $\begin{array}{c}\text { acoustic } \\
\text { energy } \\
\text { density }\left(\mathrm{/m} \mathrm{m}^{3}\right)\end{array}$ & $\begin{array}{c}\text { relative change } \\
\text { in viability }\end{array}$ & $\begin{array}{c}\text { no. of } \\
\text { experiments }\end{array}$ \\
\hline 0 & 0 & $+0.14 \pm 0.80 \%$ & 2 \\
100 & 0.06 & $-1.1 \pm 0.57 \%$ & 2 \\
125 & 0.10 & $-3.3 \%$ & 1 \\
150 & 0.14 & $+0.30 \pm 0.71 \%$ & 2 \\
175 & 0.19 & $-2.9 \pm 0.77 \%$ & 2 \\
200 & 0.24 & $-0.98 \pm 0.64 \%$ & 3
\end{tabular}

a Experiments were conducted in flow-through mode, using cell suspension volumes of $150-269 \mathrm{~mL}$ of cell suspension, flow rate of $30 \mathrm{~mL} / \mathrm{min}$, and length of experiment from 3.3 to $6.0 \mathrm{~min}$.

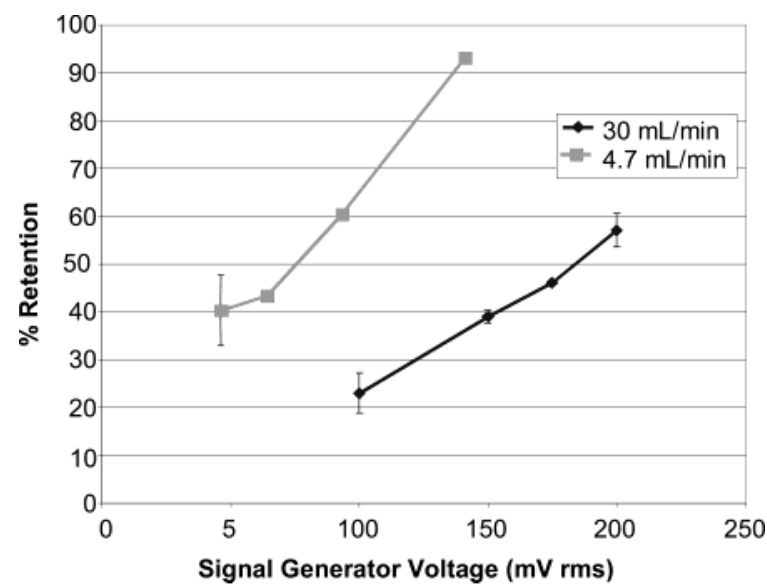

Figure 3. Hybridoma retention at different energy densities. Chamber volume $=13 \mathrm{~mL}$; mesh $=20 \mathrm{ppi}$; frequency $=1127-$ $32 \mathrm{kHz}$. ( $\diamond)$ Flow rate $=30 \mathrm{~mL} / \mathrm{min}$; \% retention determined from absorbance data from spectrophotometer, values are average readings from 4 to $6 \mathrm{~min}$ after initiation of sound field. (ם) Flow rate $=4.7 \mathrm{~mL} / \mathrm{min}$; \% retention determined from cell counts of samples from collection and feed flasks using hemocytometer at $6 \mathrm{~min}$ after initiation of sound field. Mean \pm standard deviation shown for experiments done in duplicate.

The effect of exposure to the acoustic field over extended length of time was investigated using smaller vol umes of cell feed suspension $(178 \mathrm{~mL})$ in experiments operated in recycle mode. The smaller cell suspension volume ensures that excessive cell packing and potential oxygen transport limitations did not occur in the experiments. All the cells from this sample were retained within the chamber within about 30 min of operation, and this condition was maintained for a total of $5 \mathrm{~h}$, giving an average exposure to the acoustic field of about $4.75 \mathrm{~h}$. The results in Table 1 indicate that the change in viable cell number at $125 \mathrm{mV}$ rms was not significantly different from that for the control experiment. However, at higher voltages the loss in cell viability became significant.

Exposure of the cells to the acoustic fields for short periods of time (3.3-6.0 min) had an insignificant effect on cell viability in flow-through experiments, as shown in the data in Table 2. The small changes in viability that were observed were found to be unrelated to the applied voltage. A comparison of results from Tables 1 and 2 indicate cell death occurs at higher levels of applied voltage and longer exposure times.

The percent of cells retained within the chamber is shown as a function of flow rate and applied voltage in Figure 3. As expected, the retention increases with vol tage and decreases with flow rate. When the acoustic field is deactivated, the cells are easily flushed from the chamber, indicating that the cells do not adhere to the

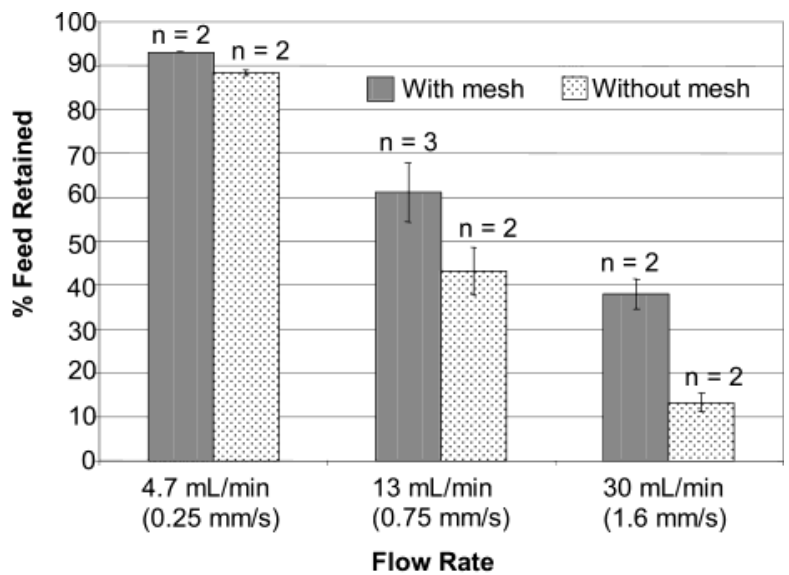

Figure 4. Hybridoma cell retention, in both the absence and presence of the mesh as a function of flow rate (at $141 \mathrm{mV} \mathrm{rms,}$ 14.5-14.9 W). Percent retention was calculated using actual cell counts of samples from the feed reservoir and the collection flask. Samples from the collection flasks were gathered during the quasi-steady period (before the breakthrough point), after four residence times.

polyester mesh. The percent retention in both the absence and presence of the mesh is shown in Figure 4, at three flow rates and applied voltage of $141 \mathrm{mV}$ rms. These results show that the mesh improves the percent retention 3-fold at the highest flow rates $(1.6 \mathrm{~mm} / \mathrm{s}, 30 \mathrm{~mL} /$ $\mathrm{min}$ ) with less influence at low flow rates studied $(0.25$ $\mathrm{mm} / \mathrm{s}$ ).

\section{Conclusions}

We have demonstrated that the collection and retention of hybridoma cells from a flowing suspension can be achieved using an acoustically driven porous polymer mesh having pore size 2 orders of magnitude larger than the cells. The energy required is moderate compared to acoustic methods that rely on aggregation at nodal planes and subsequent gravity settling. Because our method does not rely upon gravity, the device can be used in any orientation or in microgravity applications. We expect that upon optimization of several design parameters of the device and by including a cooling system to prevent natural convective flow, the retention efficiency of mammalian cells could be increased above the $95 \%$ value observed in our experiments. In addition, extremely high cell densities of over $1.5 \times 10^{8}$ cells $/ \mathrm{mL}$ have been achieved using our method. Short-term exposure to the acoustic field had negligible effect on cell viability.

\section{Acknowledgment}

Support from NASA grant NAG 8-1584 is gratefully acknowledged.

\section{References and Notes}

(1) Doblhoff-Dier, O.; Gaida, T.; Katinger, H.; Burger, W.; Groschl, M.; Benes, E. A novel ultrasonic resonance field devicefor the retention of animal cells. Biotechnol. Prog. 1994, $10,428$.

(2) Gaida, T.; Dol bhoff-Dier, O.; Strutzenberger, K.; Burger, W.; Groschl, M.; Handl, B.; Benes, E. Selective retention of viable cells in ultrasonic resonance field devices. Biotechnol Prog. 1996, 12, 73-76.

(3) Gupta, S. and Feke, D. L. Acoustically driven collection of suspended particles within porous media. Ultrasonics 1997 35, 131-139.

(4) Gupta, S.; F eke, D. L. Filtration of particulate suspensions in a acoustically driven porous media. AIChE J . 1998, 44, 1005-1014. 
(5) Kilburn, D. G.; Clarke, D. J .; Coakley, W. T.; Bardsley, D. W. Enhanced sedimentation of mammalian cells following acoustic aggregation. Biotechnol. Bioeng. 1989, 34 (4), 559562.

(6) Pui, P. W. S.; Trampler, F.; Sonderhoff, S. A.; Groeschl, M.; Kilburn, D. G.; Piret, J . M. Batch and semicontinous aggregation and sedimentation of hybridoma cells by acoustic resonance fields. Bi otechnol. Prog. 1995, 11, 146.

(7) Rusinko, D. R. Modeling of Acoustic Manipulation of Particles. MS Thesis, Case Western Reserve University, Cleveland, $\mathrm{OH}, 2000$.

(8) Ryll, T.; Dutina, G.; Reyes, A.; Gunson, J .; Krummen, L.; Etcheverry, T. Performance of small-scale $\mathrm{CHO}$ perfusion cultures using an acoustic cell filtration device for cell retention: characterization of separation efficiency and impact of perfusion on product quality. Biotechnol. Bioeng. 2000, 69 (4), 440-449.

(9) Trampler, F.; Sonderhoff, S. A.; Pui, P. W. S.; Kilburn, D. G.; Piret, J . M. Acoustic cell filter for high density perfusion culture of hybridoma cells. Bio/Technology 1994, 12, 281.

Post-print standardized by MSL Academic Endeavors, the imprint of the Michael Schwartz Library at Cleveland State University, 2014 